\title{
ROMA NÉPESSÉG ÉS OKTATÁSTERVEZÉS
}

\author{
PAPP Z. ATTILA ${ }^{a, b}$ \\ Társadalomtudományi Kutatóközpont Kisebbségkutató Intézet \\ ${ }^{\mathrm{b}}$ Miskolci Egyetem BTK ATTI
}

Beérkezett: 2021. április 19., elfogadva: 2021. június 6.

\begin{abstract}
A tanulmány népszámlálási és kutatási adatok segítségével a roma tanulókkal kapcsolatos oktatási kérdések értelmezésére, az esetleges oktatáspolitikai beavatkozások megalapozására tesz kísérletet. A szerző azt állítja, a romának gondolt tanulók jelenléte önmagában nem kellene semmilyen nyelvi-etnikai kihívást jelentsen, hiszen az esetek zömében - a népszámlálási adatok tanúsága szerint - szintén magyar anyanyelvű népességről van szó. Az igazi kihívást a roma populáció társadalmi szerkezetben elfoglalt helye jelenti: mivel az alsóbb társadalmi rétegekbe, gyakran társadalmon kívüli élethelyzetekbe szorulva élnek, ez visszahat az iskolai eredményességükre, illetve társadalmi integrációjukra is.
\end{abstract}

Kulcsszavak: roma tanulók, népszámlálási adatok, iskolai teljesítmény, területi adatok

Based on census and research data the study tries to analyse the educational situation of Roma students, and it intends to describe some educational policy interventions. According to the author the school presence of the Roma students is not an ethnic or linguistique question as Hungarian language is their mother tongue. The real challenge is the social situation of the Roma population: as they live in lower social strata, often in underclass situation, this has an impact on their school performance, and finally on their social integration.

Keywords roma student, census data, school performance, regional data

Levelező szerző: Papp Z. Attila, Társadalomtudományi Kutatóközpont Kisebbségkutató Intézet, 1097 Budapest, Tóth Kálmán u. 4.E-mail: pappz.attila@tk.hu 
A roma lakosság demográfiai viszonyai, azon belül az iskolai népesség jellemzői évtizedek óta megoldásra váró helyet foglalnak el a magyar és általában az európai, de főleg a kelet-közép-európai országok oktatáspolitikájában. Ez sok szempontból érthető is, hiszen egy sor elemzés kimutatta már, hogy a roma származású gyerekek, fiatalok és felnőttek iskolázottsági, munkaerőpiaci mutatói gyengébbek a többségéhez képest. Kellő távolságból szemlélve azonban érdekes ellentmondás feszül aközött, hogy míg a roma népességet gyakran társadalmi problémaként keretezik, addig magát az etnikai csoportot nehezen, vagy egyáltalán nem lehet hivatalos statisztikai adatokkal, objektív mércével megközelíteni. ${ }^{1} \mathrm{~A} z$ etnikai adatgyüjtésnek ugyan van hagyománya térségünkben, ám a jelenlegi hivatalos adatgyüjtések gyakorlata során vagy teljesen mellőzik, vagy jó esetben (például a népszámlálások során) az önbevallásra szorítkozhatunk. ${ }^{2}$ De a cenzusadatok alapjául szolgáló módszertanok országok között, sőt egy adott országon belül is változnak, amelynek eredményeképpen az idősoros vagy nemzetközi összehasonlítások is akadályokba ütközhetnek. ${ }^{3}$

Magyarországon például a 2001. évi népszámláláskor 205720 roma, azaz roma „nemzetiséghez tartozó” élt, míg a 2011. évi alapján ez a szám 315583. Most eltekintve attól, hogy ezek a számok más becslésekhez (pl. Pénzes-Tátrai-Pásztor 2018) képest alacsonynak tekinthetők, mégiscsak azt látjuk, hivatalosan a roma nemzetiségü egyének száma közel megkétszereződött. Felmerülhet a kérdés, pusztán 10 év alatt ilyen mértékű nemzetiségi/etnikai népességrobbanás következett be? A válasz nyilvánvaló az, hogy nem, az igazi okok valójában a két említett népszámlálás során alkalmazott etnikai adatgyüjtésre vonatkozó eltérő módszertanokra vezethetők vissza: míg 2001-ben a „nemzetiséghez tartozás" négy dimenzióra (nemzetiségi önbevallás, anyanyelv, kulturális kötődés, családban beszélt nyelv) és kérdésenként legfeljebb három válaszra, addig 2011-ben ugyanez a kategória három dimenzió két lehetséges válaszára épült (kikerült a kulturális kötődés). (Kapitány 2015; Morauszki-Papp 2014; Lajtai 2020.)

\section{A roma népesség föbb szociodemográfiai mutatói}

A népszámlálási adatok ismertetése során leggyakrabban a „nemzetiséghez tartozó” kategóriát szokták használni, és ezt az egyszerűség kedvéért roma nemzetiségűként vagy roma populációként aposztrofálják. Ha így definiáljuk a roma népességet, akkor a többé-kevésbé ismert tényekhez jutunk el: a magyarországi roma népesség területi-

\footnotetext{
Most tekintsünk el attól az antropológiai megközelítéstől, amely szerint az etnikai csoportok valójában nem léteznek, azok pusztán társadalmi konstrukciók vagy a világ dolgainak megkülönböztetésére irányuló látásmódot jelentenek (Brubaker 2001).

2 Fennáll a kockázata annak, hogy a későbbiekben erre sem lesz lehetőség, hiszen a tervek szerint 2031 után Magyarország is áttér a regiszter alapú, azaz a különféle nyilvántartásokban már létező adatok felhasználására épülő összeírásra. Ezek jelenlegi formájukban nem teszik lehetővé az etnikai önbevallást, ami akár azt is jelentheti, hogy gyakorlatilag a következő - eredetileg 2021 tavaszára, de a koronavírus-járvány miatt 2022 őszére halasztott - népszámlálás lesz az utolsó, amikor önbevallásszerűen összeírják a nemzetiségi hovatartozást. http://www.ksh.hu/sajtoszobakozlemenyektajekoztatok20210206

3 A népszámlálások adatgyưjtésére vonatkozóan nemzetközi szervezetek (pl. az ENSZ) módszertani ajánlásokat szoktak megfogalmazni, az egyes témaköröket kötelező (core topic) vagy ajánlott (non-core topic) jellegünek tekintik. Az etnikai adatgyüjtés „csak” ajánlott témakör, ami azt jelenti, hogy az országok maguk döntenek arról, hogy egyáltalán gyüjtenek-e erre vonatkozóan információkat, és ha igen, arról is, hogyan teszik ezt.
} 
leg a legnagyobb mértékben Borsodban és Szabolcsban él, és az egész népesség mintegy fele az előbb említett két megyén kívül Pest megyében, Hevesben és Budapesten él (1. táblázat). A nagyfokú regionális eltérések mellett létezik egyfajta települési lejtő is, kimutatható ugyanis, hogy a romák nagyobb arányban élnek kisebb településeken: a populáció több mint fele községekben él, és összességében 55 százalékuk 5000 fő alatti településeken (ez a magyar népesség körében csak 31 százalék).

A roma népesség átlagéletkora ugyanakkor alacsonyabb, mint a többségi társadalomé (26,3 év a magyarok 41,4 évével szemben), ami a fiatalabb korcsoportok nagyobb és az idősebbek kisebb mértékü jelenlétét is jelenti, amely közvetetten utal a magasabb termékenységi rátára és a roma nemzetiségi populáció egészségi állapotára is.

A romák körében az iskolázottsági és gazdasági mutatók gyengébbek: magasabb az alacsonyabb iskolai végzettségűek, és mindettől természetesen nem függetlenül magasabb az inaktívak aránya is. A 15 évnél idősebb roma populáció körében a 2011. évi cenzus adatai alapján a legfeljebb 8 általános iskolát végzettek aránya 85 százalék, szemben az összpopuláció mintegy 32 százalékával. Ezzel párhuzamosan az is látható a 2011. évi adatok szintjén, hogy a romák körében mindössze 16,4 százalék a foglalkoztatott, az or-

1. táblázat: A roma nemzetiséghez tartozók száma és aránya a 2011. évi népszámlálás során

\begin{tabular}{lrrcc}
\hline & Népesség & Roma & Megyék szerint & Megyén belül \\
\hline Borsod-Abaúj-Zemplén & 686266 & 58376 & 18,5 & 8,5 \\
Szabolcs-Szatmár-Bereg & 559272 & 44738 & 14,2 & 8,0 \\
Pest & 1217476 & 20719 & 6,6 & 1,7 \\
BUDAPEST & 1729040 & 20151 & 6,4 & 1,2 \\
Heves & 308882 & 19467 & 6,2 & 6,3 \\
Jász-Nagykun-Szolnok & 386594 & 19089 & 6,0 & 4,9 \\
Hajdú-Bihar & 546721 & 18546 & 5,9 & 3,4 \\
Baranya & 386441 & 17585 & 5,6 & 4,6 \\
Somogy & 316137 & 16794 & 5,3 & 5,3 \\
Nógrád & 202427 & 15489 & 4,9 & 7,7 \\
Bács-Kiskun & 520331 & 11327 & 3,6 & 2,2 \\
Békés & 359948 & 9541 & 3,0 & 2,7 \\
Tolna & 230361 & 9072 & 2,9 & 3,9 \\
Zala & 282179 & 7283 & 2,3 & 2,6 \\
Fejér & 425847 & 6497 & 2,1 & 1,5 \\
Veszprém & 353068 & 5336 & 1,7 & 1,5 \\
Csongrád & 417456 & 5006 & 1,6 & 1,2 \\
Komárom-Esztergom & 304568 & 4371 & 1,4 & 1,4 \\
Györ-Moson-Sopron & 447985 & 3511 & 1,1 & 0,8 \\
Vas & 256629 & 2685 & 0,9 & 1,0 \\
\hline Ország összesen & 9937628 & 315583 & 100 & 3,2 \\
\hline & & & & \\
\hline
\end{tabular}


szágos 40 százalékhoz képest. Ha csak a gazdaságilag aktív populációt nézzük, a romák körében 45 százalékos volt a munkanélküliség, míg országos szinten ez csak 13 százalékot tett ki. Az is kimutatható továbbá, hogy a roma nők rendszerint még inkább ki vannak téve a társadalmi dezintegráció, a munkanélküliség és alulképzettség veszélyének, mint a roma férfiak.

Fontos kihangsúlyozni azonban, hogy úgy tünik, a harmadik évezred második évtizedében jelentős elmozdulások tapasztalhatók. Ennek oka lehet adatregisztrációsmódszertani is, de utalhat tényleges társadalmi folyamatokra (például a közmunka hatására) is, ám tény, a KSH kiadványokban és más kutatási beszámolókban is egyre kedvezőbbek a roma népesség gazdasági tevékenységére utaló mérőszámok. Már a 2016. évi mikrocenzus adatai is azt jelzik, hogy a romák körében megnőtt a foglalkoztatottak aránya (16,4-ről 29,8 százalékra), és szintén kedvező tendenciáról számol be a Magyar

2. táblázat: Iskolázottsági mutatók a roma és nem roma népesség körében (2010-2017, \%)

\begin{tabular}{|c|c|c|c|c|c|c|c|c|}
\hline & 2010 & 2011 & 2012 & 2013 & 2014 & 2015 & 2016 & 2017 \\
\hline \multicolumn{9}{|c|}{ A legfeljebb alapfokú iskolai végzettségü népesség aránya } \\
\hline Ország összesen & 28,5 & 27,8 & 26,6 & 25,5 & 24,4 & 23,8 & 23,2 & 22,1 \\
\hline Roma &.. &.. &.. & 81,5 & 81,2 & 78,4 & 80,4 & 80,2 \\
\hline Nem roma &. &. &.. & 23,2 & 22,9 & 21,8 & 21,3 & 20,4 \\
\hline \multicolumn{9}{|c|}{ Alapfokú oktatásban részt vevö 15-24 évesek aránya } \\
\hline Ország összesen & 3,1 & 3,2 & 1,7 & 2,1 & 1,9 & 2,0 & 2,3 & 2,6 \\
\hline Roma &. &. &. & 5,0 & 5,6 & 6,2 & 7,5 & 7,7 \\
\hline Nem roma & .. &. &.. & 1,3 & 1,4 & 1,7 & 2,0 & 2,2 \\
\hline \multicolumn{9}{|c|}{ Középfokú oktatásban részt vevö 15-24 évesek aránya } \\
\hline Ország összesen & 43,7 & 44,2 & 44,2 & 41,9 & 40,8 & 40,6 & 40,7 & 40,7 \\
\hline Roma & .. & .. &.. & 34,0 & 37,2 & 29,4 & 28,4 & 24,2 \\
\hline Nem roma & .. &.. &.. & 42,7 & 43,0 & 41,2 & 41,5 & 41,6 \\
\hline \multicolumn{9}{|c|}{ Felsöfokú oktatásban részt vevö 15-24 évesek aránya } \\
\hline Ország összesen & 23,1 & 22,0 & 21,8 & 20,9 & 20,5 & 20,6 & 19,3 & 18,3 \\
\hline Roma &. &. &.. & 0,7 & 0,4 & 1,7 & 0,9 & 0,8 \\
\hline Nem roma &.. &.. &.. & 22,7 & 20,9 & 21,8 & 20,4 & 19,3 \\
\hline \multicolumn{9}{|c|}{ Korai iskolaelhagyók aránya } \\
\hline Ország összesen & 10,8 & 11,4 & 11,8 & 11,9 & 11,4 & 11,6 & 12,4 & 12,5 \\
\hline Roma & .. &.. &.. & 64,2 & 57,0 & 59,9 & 61,8 & 65,3 \\
\hline Nem roma &.. &. &.. & 8,7 & 10,3 & 8,9 & 9,6 & \\
\hline \multicolumn{9}{|c|}{ Sem oktatásban, sem munkában részt nem vevök aránya a 15-24 évesek körében } \\
\hline Ország összesen & 12,6 & 13,2 & 14,8 & 15,5 & 13,6 & 11,6 & 11,0 & 11,0 \\
\hline Roma &.. &.. &.. & 47,0 & 38,2 & 40,9 & 37,6 & 38,2 \\
\hline Nem roma &.. &.. &.. & 13,6 & 12,7 & 9,8 & 9,5 & 9,4 \\
\hline
\end{tabular}

Forrás: Bernáth 2018 
Statisztikai Évkönyv 2019-es kiadása is. Több felmérés adatait használva, a 2010-es évek trendjeit összegezve egy másik elemzés is arról számol be, hogy 2018-ra a romák foglalkoztatási adatai javultak, a munkanélküliségi ráta és a társadalmi kirekesztettségben élők aránya csökkent (Bernát 2018, ld. 2. táblázat).

Ezen adatokra építve oktatástervezési szempontból egyértelműen adódik, hogy a roma gyerekek iskolai sikeréért továbbra is célzottan, regionális-területi szempontokat is figyelembe véve kell tevékenykedni, a korai lemorzsolódást meg kellene akadályozni, külön programokkal kellene a kisebb települések kihívásait kezelni. Szintén célzott programokkal lehetne támogatni a családtervezést, és célzott képzésekkel kezelni kellene a nők többszörös hátrányos helyzetét is. A populáció átlagéletkora, illetve hátrányosabb helyzetü munkaerőpiaci jelenléte ugyanakkor jelzi azt is, hogy a magyar oktatási rendszernek mondhatni folyamatosan számolnia kell a szegényebb társadalmi környezetből származó roma gyerekek jelenlétével.

\section{A nemzetiségi-kisebbségi identitással kapcsolatos mutatók}

Mint jeleztük, az utóbbi cenzusok során, a nemzetiséghez tartozás mérésekor olyan sajátos módszertant alkalmaztak, amelyek különféle nemzetiségi azonosulási mintázatokat tesznek lehetővé, és kérdésként merülhet fel, van-e valamilyen összefüggés a kisebbségi identitás és az iskolázottsági adatok között. A 3. táblázat az identitásmintázatokat öszszegző adatsorokat, azaz az anyanyelvi, a nemzetiségi és a "nemzetiséghez tartozókra” vonatkozó 2001. és 2011. évi cenzus, valamint az időben közelebbi, 2016. évi mikrocenzus adatait tartalmazza. Fontos tudni, hogy ezen utóbbi alkalmával is a „nemzetiséghez való tartozást” a 2011. évi népszámlálás során alkalmazott módszertant alkalmazták (azaz a nemzetiségi önbevallás, az anyanyelv, ${ }^{4}$ illetve a családi, baráti közösségben beszélt nyelv említését, valamint ezek különféle kombinációit vették figyelembe).

A nemzetiséghez tartozók összlétszáma a 2011. évi cenzus során az előző népszámlálás adataihoz képest megugrott. A 2016. évi mikrocenzus 309632 fó roma nemzetiséghez tartozót mutatott ki, és - mintegy alátámasztva korábbi állításunkat is - ez a szám nagyságrendileg nem változott a 2011. évi teljes körű népszámlálás összeírásához képest, feltételezhető módon éppen a hasonló módszertan miatt. Mindhárom adatfelvétel során a csak anyanyelv szerinti azonosulás a roma nemzetiséghez meglehetősen alacsony (2011-ben és 2016-ban is mintegy 0,3 százalékát tette ki a célpopulációnak), és általában is kijelenthető, hogy a valamelyik romani/cigány nyelv ismerete vagy családi-baráti körben való használata egyre kisebb mértékben játszik szerepet a nemzetiségi azonosulásban: míg 2001-ben a lovári vagy beás anyanyelv a nemzetiséghez tartozók közel egynegyedénél szerepet játszott, addig ez az arány 2016-ra 12,8 százalékra lecsökkent. Igaz, az abszolút számok szintjén nincs csökkenés, ám a nemzetiség határai időközben „kitágultak”. ${ }^{5}$ Ez természetesen arról árulkodik, hogy a magyarországi roma népesség nagy része nyelvileg asszimilálódott, és elsősorban a magyar nyelvet tekinti anyanyelvének. Az is szembetűnő, hogy a 2001-es adatsorban a kifejezetten kulturális kötődés meglehetősen alacsony, ez a kulturális alapú azonosulás a többi tényezővel

\footnotetext{
4 A legutolsó két cenzus során nem teljesen egyformán mérték az anyanyelvet: 2001-ben három, 2011-ben már csak két nyelvet tüntethettek fel.

5 Sajnos az összesítésekben nem derül ki, melyik nyelvről van szó.
} 
karöltve, elsősorban a nemzetiséggel kapcsolódva jelenik meg. Oktatáspolitikai szempontból ebből azt a tanulságot talán levonhatjuk, hogy a roma nemzetiséget kulturális vagy nyelvi oktatási programokkal megcélozni nem lehet elégséges vállalkozás. Ez nem azt jelenti, ne lenne fontos a kisebbségi nyelvek és kultúrák megőrzését célzó programokat működtetni, hiszen a nyelv megtartása, ápolása bármilyen kisebbségi csoport és ugyanakkor a többségi társadalom számára is fontos kulturális örökségnek tekinthető. Mindezt ráadásul a hazai és nemzetközi kisebbségvédelmi jogi keretek is biztosítják. ${ }^{6}$

3. táblázat: A roma nemzetiséghez tartozás mintázatai

\begin{tabular}{|c|c|c|c|c|c|c|}
\hline & \multicolumn{2}{|c|}{2001} & \multicolumn{2}{|l|}{2011} & \multicolumn{2}{|c|}{2016} \\
\hline & szám szerint & $\%$ & szám szerint & $\%$ & szám szerint & $\%$ \\
\hline Csak nemzetiség (N) & 66103 & 32,13 & 244834 & 77,58 & 252434 & 81,53 \\
\hline Csak anyanyelv (ANy) & 2109 & 1,03 & 1028 & 0,33 & 1119 & 0,36 \\
\hline $\begin{array}{l}\text { Csak a családi, baráti } \\
\text { közösségben használt nyelv } \\
(\mathrm{HNy})\end{array}$ & 3080 & 1,50 & 3496 & 1,11 & 5108 & 1,65 \\
\hline $\begin{array}{l}\text { Nemzetiség és anyanyelv } \\
(\mathrm{N}+\text { Any })\end{array}$ & 1029 & 0,50 & 8578 & 2,72 & 5139 & 1,66 \\
\hline $\begin{array}{l}\text { Nemzetiség és a családi, baráti } \\
\text { közösségben használt nyelv } \\
(\mathrm{N}+\mathrm{HNy})\end{array}$ & 1123 & 0,55 & 12914 & 4,09 & 12215 & 3,95 \\
\hline $\begin{array}{l}\text { Nemzetiség, anyanyelv és a } \\
\text { családi, baráti közösségben } \\
\text { használt nyelv }(\mathrm{N}+\mathrm{Any}+\mathrm{HNy})\end{array}$ & 1021 & 0,50 & 42631 & 13,51 & 29554 & 9,54 \\
\hline $\begin{array}{l}\text { Anyanyelv, a családi, baráti } \\
\text { közösségben használt nyelv } \\
(\mathrm{ANy}+\mathrm{HNy})\end{array}$ & 2047 & 1,00 & 2102 & 0,67 & 4063 & 1,31 \\
\hline Csak kulturális kötődés (K) & 6146 & 2,99 & - & - & - & - \\
\hline $\begin{array}{l}\text { Nemzetiség és kulturális } \\
\text { kötődés }(N+K)\end{array}$ & 72966 & 35,47 & - & - & - & - \\
\hline $\begin{array}{l}\text { Kulturális kötődés és a } \\
\text { nemzetiség, anyanyelv, családi, } \\
\text { baráti körben használt nyelv } \\
\text { kombinációi - összesen }\end{array}$ & 50096 & 24,35 & - & - & - & - \\
\hline $\begin{array}{l}\text { ÖSSZESEN „nemzetiséghez } \\
\text { tartozó" }\end{array}$ & 205720 & 100 & 315583 & 100 & 309632 & 100 \\
\hline $\begin{array}{l}\text { - ebből, akik az anyanyelvet is } \\
\text { említették }\end{array}$ & 48438 & 23,55 & 39875 & 17,22 & 54339 & 12,88 \\
\hline $\begin{array}{l}\text { - ebből, akik a nemzetiséget is } \\
\text { említették }\end{array}$ & 189984 & 92,35 & 299342 & 97,90 & 308957 & 96,68 \\
\hline
\end{tabular}

Forrás: KSH

6 Ld. a Kisebbségi Keretegyezményt, különösen az 5. és 14. cikkeket. https://net.jogtar.hu/jogszabaly? docid $=99900034 . \mathrm{TV}$ 
A hazai hivatalos adatok tehát arról árulkodnak, hogy a roma nemzetiség esetében a lovári vagy beás nyelvismeret kis mértékben bír identitásképző funkcióval, és a cenzusok során voltaképpen a nemzetiségi önbevallás a meghatározó. Láthatjuk például (3. táblázat), hogy a két utolsó összeírás (a 2011. évi népszámlálás és a 2016. évi mikrocenzus) során a "nemzetiséghez tartozó" kategória és nemzetiségi önbevallást valamilyen módon tartalmazó azonosulás majdnem teljesen lefedi egymást: az utóbbi kategória az előbbi mintegy 97-98 százalékát kiteszi. Igaz, árnyalatnyi különbségek léteznek: a nemzetiségi hovatartozásra vonatkozó két kérdésre adott válaszok önmagukban kiteszik a nemzetiséghez tartozók 76-82 százalékát.

Mivel a két utolsó hivatalos adatgyüjtés során a nemzetiségi hovatartozás kérdései külön szerepeltek, lehetőség nyílik az elsőként és másodikként említett roma nemzetiségi hovatartozás körülírására is. Akik elsőként említették a roma nemzetiséget, „elsősorban” romának tartják magukat, és annak függvényében, hogy említettek vagy sem még egy második nemzetiséget, megkülönböztethetjük a „csak roma” és „roma - valamilyen más” kategóriákat. A KSH-tól kapott (eddig nem publikált) adatok alapján azonban tudjuk, hogy utóbbi kategória elsősorban „roma-magyar” csoportot jelöl, hiszen nagyon kevesen

4. táblázat: $A z$ iskolai végzettség és a nemzetiséghez tartozás kritériumai a 2011. évi cenzus és a 2016. évi mikrocenzus során*

\begin{tabular}{|c|c|c|c|c|c|c|}
\hline & 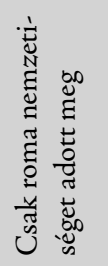 & 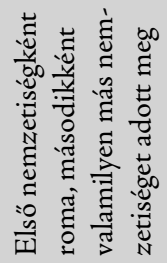 & 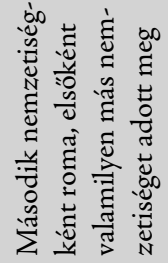 & 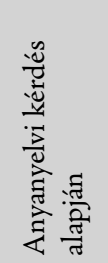 & 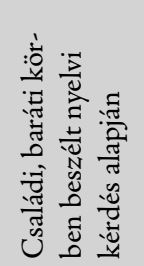 & $\begin{array}{l}Z \\
\text { w } \\
\text { N } \\
\text { N } \\
\text { N } \\
: 0\end{array}$ \\
\hline $\begin{array}{l}\text { Identitás- } \\
\text { csoportok }\end{array}$ & $\begin{array}{l}\text { „csak } \\
\text { roma” }\end{array}$ & $\begin{array}{l}\text { "roma- } \\
\text { magyar" }\end{array}$ & $\begin{array}{c}\text { "magyar- } \\
\text { roma" }\end{array}$ & $\begin{array}{l}\text { anya- } \\
\text { nyelvi }\end{array}$ & $\begin{array}{c}\text { nyelv- } \\
\text { használati }\end{array}$ & $\begin{array}{l}\text { nemzetiség- } \\
\text { hez tartozó }\end{array}$ \\
\hline Iskolai végzettség & \multicolumn{6}{|c|}{2011} \\
\hline $\begin{array}{l}\text { Általános iskola } \\
\text { 8. évfolyamnál } \\
\text { alacsonyabb }\end{array}$ & 39119 & 23981 & 84323 & 25896 & 28053 & 149960 \\
\hline $\begin{array}{l}\text { Általános iskola } \\
\text { 8. évfolyam }\end{array}$ & 31875 & 21038 & 68767 & 22624 & 26002 & 124357 \\
\hline $\begin{array}{l}\text { Középfokú } \\
\text { iskola érettségi } \\
\text { nélkül, szakmai } \\
\text { oklevéllel }\end{array}$ & 6586 & 4539 & 15963 & 4103 & 4807 & 27884 \\
\hline Érettségi & 2359 & 1751 & 6232 & 1377 & 1796 & 10775 \\
\hline $\begin{array}{l}\text { Egyetem, } \\
\text { fóiskola stb. } \\
\text { oklevéllel }\end{array}$ & 506 & 476 & 1442 & 339 & 485 & 2607 \\
\hline ÖSSZESEN & 80445 & 51785 & 176727 & 54339 & 61143 & 315583 \\
\hline$\%$ & 25,5 & 16,4 & 56,0 & 17,2 & 19,4 & - \\
\hline
\end{tabular}




\section{4, táblázat: $\left(f_{o l y t}\right)$}

\begin{tabular}{|c|c|c|c|c|c|c|}
\hline & 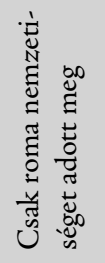 & 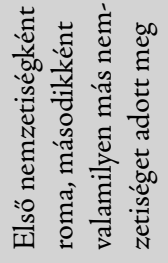 & 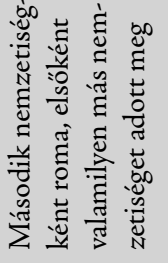 & 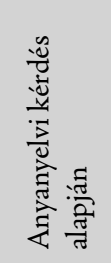 & 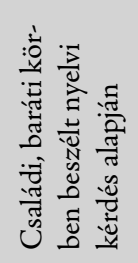 & 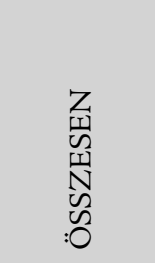 \\
\hline $\begin{array}{l}\text { Identitás- } \\
\text { csoportok }\end{array}$ & $\begin{array}{l}\text { "csak } \\
\text { roma" }\end{array}$ & $\begin{array}{l}\text { "roma- } \\
\text { magyar" }\end{array}$ & $\begin{array}{l}\text { "magyar- } \\
\text { roma" }\end{array}$ & $\begin{array}{l}\text { anya- } \\
\text { nyelvi }\end{array}$ & $\begin{array}{c}\text { nyelv- } \\
\text { használati }\end{array}$ & $\begin{array}{l}\text { nemzetiség- } \\
\text { hez tartozó }\end{array}$ \\
\hline Iskolai végzettség & \multicolumn{6}{|c|}{2016} \\
\hline $\begin{array}{l}\text { Általános iskola } \\
\text { 8. évfolyamnál } \\
\text { alacsonyabb }\end{array}$ & 28192 & 9588 & 90352 & 16483 & 20073 & 131763 \\
\hline $\begin{array}{l}\text { Általános iskola } \\
\text { 8. évfolyam }\end{array}$ & 32225 & 11278 & 82257 & 18485 & 23878 & 130234 \\
\hline $\begin{array}{l}\text { Középfokú } \\
\text { iskola érettségi } \\
\text { nélkül, szakmai } \\
\text { oklevéllel }\end{array}$ & 7421 & 2803 & 18879 & 3421 & 4630 & 30278 \\
\hline Érettségi & 3348 & 1170 & 9373 & 1215 & 1905 & 14639 \\
\hline $\begin{array}{l}\text { Egyetem, } \\
\text { fóiskola stb. } \\
\text { oklevéllel }\end{array}$ & 649 & 226 & 1581 & 271 & 454 & 2718 \\
\hline ÖSSZESEN & 71835 & 25065 & 202442 & 39875 & 50940 & 309632 \\
\hline$\%$ & 23,20 & 8,10 & 65,38 & 12,88 & 16,45 & - \\
\hline
\end{tabular}

* Mivel egy személy értelemszerűen csak egy iskolai végzettséggel, ám a nemzetiséghez tartozás kritériumai szintjén többel is rendelkezhet, a sor szerinti összesítések meghaladják az Összesen (nemzetiséghez tartozó) oszlop adatait, az oszlop szerinti összesítések természetesen megegyeznek az utolsó sor Összesen adataival.

Forrás: $\mathrm{KSH}$

említettek a magyartól eltérő nemzetiséget (2011-ben 1063 fó, 2016-ban 506 fó). Akik a roma nemzetiséget csak a második kérdés kapcsán említették, szintén többes („valami más - roma”) kötődésűek, ám mivel első helyen majdnem kizárólag a magyart említették, „magyar-roma” kötődésűeknek tekinthetjük. Egyébként az összes magyarországi nemzetiség vonatkozásában kijelenthető, hogy az ismertetett módszertan alapján kb. 90 százalékban magyar nemzetiségüeknek is tekinthetők, és ez - éppen a romani anyanyelv hiányában - a romákra még inkább érvényes ( 99 százalékban magyarok is) (Lajtai 2020). Kérdés lehet azonban, hogy van-e valamilyen kitapintható különbség az elsősorban romaként definiált („csak roma”, „roma-magyar”) csoportok, illetve az egyértelmüen többes kötődésűek („magyar-romák”) között? Ugyanígy felmerülhet az is, hogy a nyelvi alapon nemzetiséghez tartozóknak van-e értelmezhető sajátosságuk a nemzetiségi önazonosulással jellemezhető csoportokhoz képest? Előzetes feltételezésként azt fogalmazhatjuk meg, hogy azok, akik a roma nemzetiséget csak másodsorban említették (azaz elsősorban 
5. táblázat: Az iskolai végzettség a nemzetiséghez tartozás kritériumain belül a 2011. évi cenzus és a 2016. évi mikrocenzus során

\begin{tabular}{|c|c|c|c|c|c|c|}
\hline & 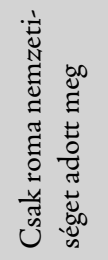 & 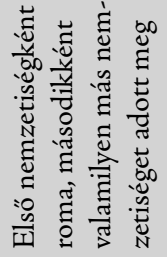 & 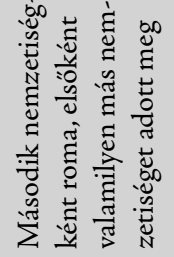 & 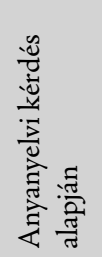 & 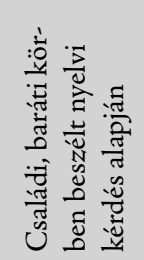 & 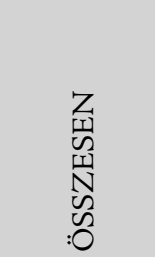 \\
\hline $\begin{array}{l}\text { Identitás- } \\
\text { csoportok }\end{array}$ & $\begin{array}{l}\text { "csak } \\
\text { roma" }\end{array}$ & $\begin{array}{l}\text { "roma- } \\
\text { magyar" }\end{array}$ & $\begin{array}{l}\text { "magyar- } \\
\text { roma" }\end{array}$ & $\begin{array}{l}\text { anya- } \\
\text { nyelvi }\end{array}$ & $\begin{array}{c}\text { nyelv- } \\
\text { használati }\end{array}$ & $\begin{array}{l}\text { nemzetiség- } \\
\text { hez tartozó }\end{array}$ \\
\hline Iskolai végzettség & \multicolumn{6}{|c|}{2011} \\
\hline $\begin{array}{l}\text { Általános iskola } \\
\text { 8. évfolyamnál } \\
\text { alacsonyabb }\end{array}$ & 48,6 & 46,3 & 47,7 & 47,7 & 45,9 & 47,5 \\
\hline $\begin{array}{l}\text { Általános iskola } \\
\text { 8. évfolyam }\end{array}$ & 39,6 & 40,6 & 38,9 & 41,6 & 42,5 & 39,4 \\
\hline $\begin{array}{l}\text { Középfokú } \\
\text { iskola érettségi } \\
\text { nélkül, szakmai } \\
\text { oklevéllel }\end{array}$ & 8,2 & 8,8 & 9,0 & 7,6 & 7,9 & 8,8 \\
\hline Érettségi & 2,9 & 3,4 & 3,5 & 2,5 & 2,9 & 3,4 \\
\hline $\begin{array}{l}\text { Egyetem, } \\
\text { fóiskola stb. } \\
\text { oklevéllel }\end{array}$ & 0,6 & 0,9 & 0,8 & 0,6 & 0,8 & 0,8 \\
\hline ÖSSZESEN & 100 & 100 & 100 & 100 & 100 & 100 \\
\hline Iskolai végzettség & \multicolumn{6}{|c|}{2016} \\
\hline $\begin{array}{l}\text { Általános iskola } \\
\text { 8. évfolyamnál } \\
\text { alacsonyabb }\end{array}$ & 39,2 & 38,3 & 44,6 & 41,3 & 39,4 & 42,6 \\
\hline $\begin{array}{l}\text { Általános iskola } \\
\text { 8. évfolyam }\end{array}$ & 44,9 & 45,0 & 40,6 & 46,4 & 46,9 & 42,1 \\
\hline $\begin{array}{l}\text { Középfokú } \\
\text { iskola érettségi } \\
\text { nélkül, szakmai } \\
\text { oklevéllel }\end{array}$ & 10,3 & 11,2 & 9,3 & 8,6 & 9,1 & 9,8 \\
\hline Érettségi & 4,7 & 4,7 & 4,6 & 3,1 & 3,7 & 4,7 \\
\hline $\begin{array}{l}\text { Egyetem, } \\
\text { fóiskola stb. } \\
\text { oklevéllel }\end{array}$ & 0,9 & 0,9 & 0,8 & 0,7 & 0,9 & 0,9 \\
\hline ÖSSZESEN & 100 & 100 & 100 & 100 & 100 & 100 \\
\hline
\end{tabular}

Forrás: KSH 
magyarként határozták meg önmagukat, „magyar-romák”), vélhetően nagyobb mértékben integrálódtak (vagy legalábbis nagyobb mértékben szeretnének integrálódni) a többségi társadalomba. Egy másik hipotézisünk az lehet, a nyelvi azonosulással rendelkezők még kevésbé integrálódtak a többi identitáscsoporthoz képest, a nyelvhasználat ilyen értelemben éppen az elkülönülés irányába mutat.

E hipotézisek ellenőrzése céljából - a KSH-kiadványokban eddig nem publikált nemzetiségi adatokra tudunk támaszkodni. ${ }^{7}$ A 4. és 5. táblázatban a két utóbbi összeírás nemzetiséghez tartozás kritériumai szerinti iskolázottsági adatokat láthatjuk. Az abszolút számok szintjén (4. táblázat) először is megállapítható, hogy mindkét cenzus során a második nemzetiségi kérdés alapján romának besoroltak száma magasabb az összes többi kategóriához képest. Ezt röviden úgy interpretálhatjuk, hogy a romák identitásában a magyar-roma kötődés a meghatározó. Érdekes, hogy a roma-magyar identitás a legkisebb mértékű mindkét cenzus során, és a második legnagyobb identitáscsoportot a „csak roma" bélyeggel ellátott csoport teszi ki.

Ha az abszolút értékeket tekintjük, megállapítható, hogy a két magasabb (az érettségi és felsőfokú) iskolai végzettség a magyar-roma nemzetiségűek körében a legmagasabb. Az iskolai végzettségeket a nemzetiséghez tartozás kritériumain belül arányosítva (5. táblázat) szintén megállapíthatjuk, hogy a "magyar-roma” csoporton belül relatív magasabb az iskolázottság, mint az ,anyanyelvi” csoporton belül. Úgy tünik tehát, hogy az identitásmintázatok szerint rétegzett roma csoportokon belül a magyar-romák a legsikeresebbek, és az anyanyelvi csoport a kevéssé sikeres mindkét összeírás adatai alapján. A két, nemzetiségi hovatartozást firtató kérdés alapján létrehozott három azonosulási csoport iskolai végzettségek szerinti eltérése viszont nem egyértelmű: a 2011. évi adatok ugyan egyértelműen alátámasztják előzetes feltételezésünket, azaz a magyarroma kötődésűek iskolai végzettsége magasabb, mint a „csak roma” nemzetiségi csoporté, a 2016. évi mikrocenzus adatai ellenben ezt nem erősítik meg. Ennek oka vagy az, hogy a mikrocenzus mintavételre épülő módszertana (a háztartások 10 százalékát mérték fel) az ilyen kisebb csoportok esetében óhatatlanul is torzítással jár, vagy elképzelhetö, hogy a nemzetiségi azonosulási stratégiák és az iskolai végzettség között nincs érdemi kapcsolat.

\section{A roma iskolai népesség és az iskolarendszer néhány sajátossága}

Magyarországon hosszú ideig a hivatalos iskolastatisztika részét képezte a roma tanulók számontartása: a korabeli minisztériumi adminisztráció kíváncsi volt arra, milyen iskolatípusokban tanulnak, és milyen mértékü az előrehaladásuk. ${ }^{8}$ Ezen forrás szerint az általános iskolai szinten 1992/93-ban például 74441 roma tanuló volt, ami az összes általános iskolás tanulóhoz képest 7,1 százalékot tesz ki.

Az 1993. évi kisebbségi törvény elfogadása után megszűnt az elsősorban minisztériumi belső használatra készült etnikai adatgyűjtés, ám érdekes módon a kompetenciamérés $(\mathrm{OKM})$ segítségével mégiscsak képet kaphatunk a romának tartott iskolai népes-

Köszönettel tartozom a KSH munkatársainak, hogy az itt közölt nemzetiségi adatokra vonatkozó kérelmemet készségesen teljesítették.

8 Az 1969/1970-es tanévtől az 1992/1993-as tanévig terjedő idősoros adatok 2004-ben Kertesi Gábor könyvében jelentek meg először nyilvánosan (Kertesi 2004). 
ség néhány jellemzőjéről, ugyanis a telephelyi kérdőívben van egy kérdésblokk, amelyben többek között rákérdeznek az intézménybe járó tanulók romaarányára is. ${ }^{9}$

Az elmúlt évek adatai alapján (1. ábra) 13-14 százalék körülire tehető az általános iskolákban a roma tanulók aránya, ${ }^{10}$ amely majdnem kétszerese a kilencvenes évek elején mért adatoknak. Ez azonban nem jelent abszolút értékben is kétszeres növekedést, mivel időközben az általános iskolai populáció is lecsökkent. E becslések alapján 2017/2018-ra (ekkor az összes általános iskolás száma 732491 volt) mintegy 107 ezerre tehető az általános iskolai roma populáció nagysága.

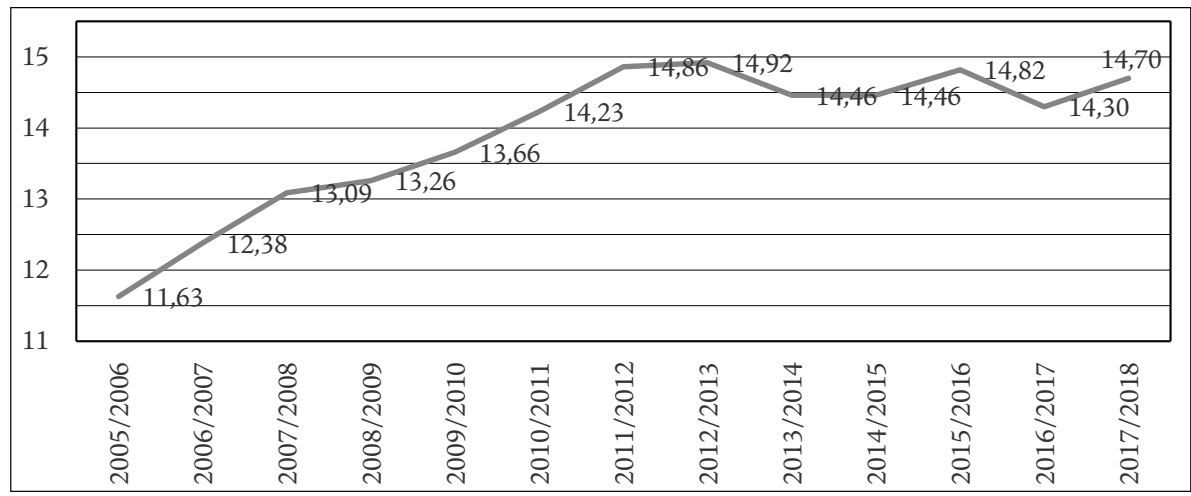

1. ábra: Az általános iskolai roma tanulók becsült aránya (saját számítás). Forrás: OKM

Oktatáspolitikai szempontból nemcsak a populáció mértéke, hanem bizonyos jellemzői, területi és intézményi koncentrációja is releváns. A rendelkezésünkre álló legutóbbi adatbázis alapján például egyértelmü, hogy a roma tanulók leginkább általános iskolai képzésbe járnak, elvétve lehet a 6 vagy 8 évfolyamos gimnáziumi képzésben megtalálni: míg az általános iskolai képzésen belül 14,7 százalékra, a gimnáziumi képzéseken belül 2,5-3 százalékra becsülték a roma tanulók arányát. Láttuk már a népszámlálási adatoknál is, hogy a roma népesség magasabb arányban él falvakban, és e települési lejtő visszaköszön az OKM-adatokból is: a roma tanulók társadalmi láthatósága falvakban magasabb, mint a nagyobb városokban.

$\mathrm{A} z$ OKM-adatok továbbá azt - a cenzusadatok szintjén látott tényt - is megerősítik, hogy a roma tanulók aránya Borsod-Abaúj-Zemplén, Szabolcs-Szatmár-Bereg és Nógrád megyében a legmagasabb. Ugyanakkor településtípus szerint is vizsgálva a megyei adatokat, láthatjuk, hogy a borsodi községekben tanuló gyerekek több mint fele, a szabolcsiaknak és nógrádiaknak közel fele, a baranyai, hajdú-bihari és hevesi községi tanulóknak pedig harmada roma származású.

A területi koncentrációt járások szintjén is vizsgálva, megállapíthatjuk, hogy 14 helyen a tanulók több mint fele roma származású (Cigándi, Edelényi, Encsi, Szikszói, Pétervásárai, Ózdi, Gönci, Jászapáti, Vásárosnaményi, Tiszavasvári, Hevesi, Sellyei,

9 A korábbi minisztériumi iskolastatisztikák és az OKM-adatok is külső értékelésnek, heteroidentifikációnak minősülnek, azaz a helyi intézményi szereplők helyi becslésének számítanak.

10 Módszertani szempontból fontos rögzíteni, hogy természetesen minden évben találkozni adathiánnyal, amely torzíthatja az eredményeket. Az általunk itt használt 2017/2018-as tanévre vonatkozó adatok során a romaarányt tudakoló kérdésre a telephelyek 12 százaléka nem válaszolt. 
6. táblázat: A roma tanulók becsült aránya megyék és településtípus szerint (saját számítás)

\begin{tabular}{lcccc}
\hline & Község & Város & Megyeszékhely & ÖSSZESEN \\
\hline Bács-Kiskun & 10,19 & 13,51 & 6,56 & 11,09 \\
Baranya & 34,08 & 15,64 & 8,81 & 17,58 \\
Békés & 13,32 & 12,08 & 2,74 & 10,49 \\
Borsod-Abaúj-Zemplén & 53,36 & 31,05 & 14,48 & 36,39 \\
Csongrád & 4,98 & 5,37 & 3,57 & 4,49 \\
Fejér & 9,07 & 7,29 & 2,44 & 6,55 \\
Györ-Moson-Sopron & 4,72 & 2,18 & 3,26 & 3,35 \\
Hajdú-Bihar & 33,42 & 22,65 & 2,42 & 18,09 \\
Heves & 32,95 & 19,96 & 7,47 & 23,00 \\
Jász-Nagykun-Szolnok & 35,54 & 18,53 & 8,09 & 20,83 \\
Komárom-Esztergom & 4,74 & 9,11 & 11,39 & 8,30 \\
Nógrád & 44,21 & 20,80 & 25,71 & 33,83 \\
Pest & 11,52 & 6,87 & & 8,16 \\
Somogy & 34,90 & 15,29 & 8,43 & 20,57 \\
Szabolcs-Szatmár-Bereg & 47,08 & 27,50 & 6,63 & 31,7 \\
Tolna & 27,12 & 11,35 & 6,70 & 16,08 \\
Vas & 5,23 & 5,99 & 1,43 & 4,06 \\
Veszprém & 10,13 & 8,04 & 2,95 & 7,72 \\
Zala & 23,07 & 7,40 & 3,88 & 11,85 \\
BUDAPEST & - & - & - & 5,70 \\
\hline ÖSSZESEN & 26,08 & 13,67 & 6,21 & 14,42 \\
\hline Foras: OKM2018 & & &
\end{tabular}

Forrás: OKM 2018

Szécsényi, Kunhegyesi), és nem elenyésző azon járásoknak a száma sem, ahol 30-50 százalékos becsült arányt találhatunk. A budapesti járások közül a VIII. kerületi tanulók harmadáról gondolták azt az OKM-adatszolgáltatók, hogy roma származásúak. Ugyan a területi besorolások változtak a járások létrehozásával, de összehasonlításképpen érdemes felidézni, hogy például 2009-ben csak három kistérségen belül volt 50 százalékot meghaladó becsült romaarány.

A szakirodalomban a 30-50 százalék közötti romaaránnyal rendelkező térségeket vagy iskolákat gettósodónak, az 50 százalék fölöttieket gettósodott területeknek vagy gettóiskolának szokták nevezni. Ha viszont a vizsgált egységeken belül figyelembe veszszük a romaarány átlagának szórását is, árnyaltabb képet kaphatunk. A járásokon belüli romaarány szórása ugyanis a járási szintű szegregáció mértékéről árulkodik: minél magasabb a szórás, annál heterogénebbek a járáshoz tartozó települések, azaz a járáson belül vannak iskolák, ahol alacsony, és vannak olyanok, ahol magasabb a romaarány. Értelemszerűen a fordított esetekben, azaz ahol alacsony a járási szintre aggregált szórás, az azt jelenti, az iskolák a romaarány vonatkozásában relatív homogének. Ha a szórás értékét a járási szintű szegregáció indikátoraként használjuk és figyelembe vesszük 
7. táblázat: Járástípusok az iskolai etnikai szegregáció jellege szerint (saját számítás, klaszterelemzés az OKM 2018 alapján)

\begin{tabular}{lcccc}
\hline & $\begin{array}{c}\text { Nem } \\
\text { szegregáló }\end{array}$ & $\begin{array}{c}\text { Mérsékelten } \\
\text { szegregáló }\end{array}$ & $\begin{array}{c}\text { Gettósodott } \\
\text { szegregáló }\end{array}$ & $\begin{array}{c}\text { Gettósodó } \\
\text { szegregáló }\end{array}$ \\
\hline Romaarány átlaga & 5,93 & 18,21 & 56,09 & 36,73 \\
$\begin{array}{l}\text { Romaarány szórásának } \\
\text { átlaga }\end{array}$ & 8,04 & 20,96 & 33,09 & 26,32 \\
$\begin{array}{l}\text { Romaarány szórásának } \\
\text { terjedelme (min.-max.) }\end{array}$ & $0,5-16,9$ & $11,1-31,1$ & $12,3-43,4$ & $10,9-36,8$ \\
Járások száma & 105 & 45 & 16 & 31 \\
Járások aránya (\%) & 62,90 & 21 & 5 & 11,10 \\
\hline
\end{tabular}

a járási szintre aggregált romaarányt is, klaszterelemzéssel a járásokat négy csoportba sorolhatjuk (ld. 7. táblázat): 1. nem szegregáló járásoknak tekinthetjük azokat, ahol elenyésző a roma jelenlét az összes járásbeli településen (a romaarány és a szórás is alacsony); 2. mérsékelten szegregáló járások azok, amelyekben az átlag fölötti mérsékelt romaarány enyhén átlag fölötti szórással társul; 3. gettósodott szegregáló járások azok, ahol a magas romaarány magas szórással is jár; 4. gettósodó szegregáló járások azok, amelyekben magas a romaarány, a szórás viszont átlagos.

Láthatjuk, a gettósodás mértéke mindig együttjár valamiféle térségi szegregációval, ami egyértelműen jelzi, hogy a gettósodás nem pusztán egy adott térségen belüli romaaránynak köszönhető, hanem a települések, illetve az iskolák közötti - romaarányban mért - különbségeknek is. Ez azt jelenti, ritkán találni olyan járást, ahol a magas romaarány alacsony szórással társulna. Kivételek persze vannak: a gettósodott szegregáló típusba tartozó 16 járás között csak a cigándi és a pétervásárai járások olyanok, ahol minden iskolában relatív magas a roma gyerekek aránya, a többi járás esetében találni legalább egy alacsony romaaránnyal rendelkező intézményt is: e csoportba tartozik például az edelényi és az encsi járás is, ahol éppen az egyik városi - egyébként egyházi fenntartású - általános iskolában alacsony a roma tanulók aránya. Az ilyen adatok újra előtérbe hozzák a településtípus szerinti különbözőségeket (a roma tanulók aránya a községi iskolákban rendszerint magasabb), és utalnak az elmúlt évtizedben - az állam által támogatott-finanszírozott, és ezért - dinamikusan fejlődő egyházi fenntartású iskolák térségi szegregációban játszott szerepére is. ${ }^{11}$ Jelen tanulmánynak nem célja az egyházi iskolák részletes tárgyalása, ám annyit jelezhetünk, hogy míg az általános iskolák szintjen 14,4 százalékos romaarányt mutatnak a rendelkezésünkre álló legutóbbi, 2018. évi adatok, ez a szám az egyházi fenntartású intézményekben átlagosan csak 10,4 százalék. ${ }^{12}$

Ha az intézményeket/telephelyeket vizsgáljuk, beazonosíthatjuk a 30-50 százalékos, illetve az 50 százalék fölötti romaaránnyal rendelkező gettósodó és gettóiskolákat is: 2018-ban előbbibe 369 iskolát, utóbbiba 249 intézményt sorolhatunk. Idősorosan azt is

11 Érdekes módon és következmények nélkül az egyházi iskolák e szerepét még az Innovációs és Technológiai Minisztérium számára készült Magyar Nemzeti Társadalmi Felzárkózási Stratégia érvényesülésének értékelése c. dokumentum is jelzi. pp. 90-91.

12 Az egyházi iskolák térnyeréséről és hatásairól ld. Fejes-Szücs 2018. Bővebb adatokat ld. még: Varga 2019. 
8. táblázat: A gettóiskolák és a gettósodó iskolák száma az OKM-adatok alapján

\begin{tabular}{lccc}
\hline & Gettóiskola & Gettósódó iskola & ÖSSZESEN \\
\hline 2008 & 275 & 300 & 575 \\
2009 & 296 & 302 & 598 \\
2010 & 311 & 285 & 596 \\
2011 & 313 & 296 & 609 \\
2012 & 320 & 267 & 587 \\
2013 & 331 & 274 & 605 \\
2014 & 339 & 273 & 612 \\
2015 & 350 & 261 & 611 \\
2016 & 377 & 260 & 637 \\
2017 & 366 & 246 & 612 \\
2018 & 369 & 249 & 618 \\
\hline
\end{tabular}

Forrás: 2008-2016: Ercse 2018; 2017-2018: saját számítás

megállapíthatjuk (8. táblázat), hogy a 2010-es évek elejéhez képest ${ }^{13}$ egyre növekvő intézményi szegregálódásra utalnak az adatok: a gettósodó iskolák száma részben csökkent, mert átbillentek a gettóiskola kategóriába, ám a kétféle szegregálódó intézmény együttes száma folyamatosan növekedett. Mindez jelzi, hogy a térségi/iskolai szegregálódás az elmúlt bő évtizedben folyamatosan zajlott.

Mivel kompetenciamérésből származó adatokról van szó, rögtön adódik a kérdés: Milyen összefüggés van az intézményi becsült romaarány és az intézményi/telephelyi szintre aggregált kompetenciaértékek között? Az ilyen adatok bemutatása gyakran érzékeny szokott lenni, adott esetben félrevezető lehet vagy társadalmi elöítéleteket is megerősíthet, hiszen akár korábbi évek adatbázisán vizsgálódunk (ld. pl. Papp 2011), akár a legfrissebb adatokat elemezzük, kimutatható, hogy a növekvő romaarány együttjár a kompetenciaértékek csökkenésével is (9. táblázat, 1. modell). Csakhogy, ez valójában

9. táblázat: A matematikai és szövegértési kompetenciákat magyarázó tényezők (lineáris regressziós modellek, béta-együtthatók)

\begin{tabular}{|c|c|c|c|c|c|c|}
\hline & \multicolumn{3}{|c|}{ Matematika } & \multicolumn{3}{|c|}{ Szövegértés } \\
\hline & 1. modell & 2. modell & 3. modell & 1. modell & 2. modell & 3. modell \\
\hline Romaarány & $-0,64^{*}$ & $-0,08^{\star}$ & $-0,10^{*}$ & $-0,69^{*}$ & $-0,14^{*}$ & $-0,15^{*}$ \\
\hline CSHI index & & $0,73^{*}$ & $0,73^{*}$ & & $0,72^{*}$ & $0,71^{*}$ \\
\hline $\begin{array}{l}\text { Cigány nemzetiségi } \\
\text { program }\end{array}$ & & & $-0,04^{*}$ & & & $-0,03^{*}$ \\
\hline$R^{2}(\%)$ & 42 & 63 & 64 & 47 & 68 & 68 \\
\hline
\end{tabular}

*szignifikáns hatás $(p<0,01)$

13 Más kutatási forrásokból azt is tudjuk, hogy 2000-ben 126, 2004-ben pedig 178 gettóiskola volt (HavasLiskó 2005). Ezen évszámokhoz viszonyított időperspektívában még markánsabb szegregálódás mutatható ki. 
a jéghegy csúcsa, mivel ha az iskolai eredményesség magyarázó tényezői között megkülönböztetjük a „látható" és a „nehezen megfigyelhető" dimenziókat, a helyi becsült romaarány az előbbi, a családi háttér az utóbbiba tartozik. Az ellentmondás ott lapul, hogy valójában a nem látható tényezőknek van - legalábbis statisztikailag egyértelműen kimutatható - erőteljes hatása, ám a sok helyen tapasztalható white-flight jelenség pedig a társadalmilag látható tényezőkre épül. A 2018, évi kompetenciamérés adataira építve megállapíthatjuk, hogy a családi háttér beemelése az iskolai eredményesség magyarázatába (9. táblázat, 2. modell) a matematika esetében majdnem teljesen, a szövegértés szintjén pedig nagymértékben lecsökkenti az etnikai arány jelentőségét, és mindkét kompetenciaterületen az igazi magyarázó tényező a családiháttér-index (CSHI).

A népszámlálási adatokból már leszürtük, hogy a roma népesség nagymértékben asszimilálódott, hiszen a nemzetiségi azonosulásban csak elenyésző mértékben játszik szerepet a nyelvismeret. Mindazonáltal a magyarországi oktatási rendszer különféle formákban ${ }^{14}$ lehetővé teszi a nemzetiségi (kisebbségi) oktatást és/vagy a nemzetiségi nyelvoktatást is. A roma nemzetiség esetében ez az oktatás történhet magyar nyelven is, amely adott esetben kiegészülhet nyelvoktatással is. A hivatalos statisztikai adatok szerint a roma/cigány nemzetiségi oktatás népszerűsége megcsappant az elmúlt években (általános iskolai szinten 2018/2019-ben 20406 fö vett részt benne, amely a korábbi becsléseink alapján a roma tanulók mintegy egyötödét teszi ki). A nyelvi asszimilálódást és már-már a teljes nyelvvesztést továbbá előrevetíti az is, hogy mindössze 1092 fiatal vett részt beás/romani nyelvoktatásban is. $\mathrm{Az}$ OKM-adatok továbbá lehetővé teszik azt is, hogy közelebbi képet kapjunk a cigány nemzetiségi program szerepéről és hatékonyságáról. Az adatokból (10. táblázat) egyértelműen kiderül, hogy e nemzetiségi program mondhatni csak gettósodott körülmények között müködik: nemcsak azért, mert az átlagos romaarány 65 százalék, hanem mert nagyon szegény családból származó gyerekek járnak ezekbe az iskolákba (a CSHI jóval átlag alatti: -1,34).

10. táblázat: A kompetenciaértékek, a családiháttér-index és a becsült romaarány a cigány nemzetiségi program létezésének függvényében

\begin{tabular}{lcccc}
\hline Múködik-e cigány nemzetiségi program? & Matematika & $\begin{array}{c}\text { Szöveg- } \\
\text { értés }\end{array}$ & CSHI & $\begin{array}{c}\text { Roma- } \\
\text { arány (\%) }\end{array}$ \\
\hline Igen & 1447 & 1417 & $-1,34$ & 65,3 \\
Nem & 1608 & 1595 & $-0,08$ & 12,4 \\
\hline Összesen & 1602 & 1589 & $-0,11$ & 14,4 \\
\hline
\end{tabular}

E tények ugyanakkor indirekt módon magyarázatot adnak a program népszerűségének csökkenésére is: a gettósodó (alacsonyabb romaarányú) térségekben vélhetően azért nem indítanak ilyen programokat, mert az egy újabb, romákkal kapcsolatos „látható” tényező lenne, és felerősíthetné a szülők „lábbal történő” iskolaválasztását. Statisztikai elemzéssel továbbá az is kimutatható, hogy a cigány nemzetiségi program-

\footnotetext{
14 A hatályos jogszabályok szerint a nemzetiségi oktatást-nevelést a következő formákban lehet megszervezni: anyanyelvü, kétnyelvű, nyelvoktató, magyar nyelvü roma/cigány vagy kiegészítő nemzetiségi nevelésoktatás. A nemzetiségi oktatásról részletesebben ld. Orsós 2015.
} 
nak nincs vagy alig van hatása a kompetenciákra, ${ }^{15}$ amely jelentheti azt is, hogy olyan tartalmakat közvetít, amely nincs kapcsolatban a mért szövegértési vagy matematikai kompetenciákkal, de értelmezhetjük úgy is, hogy az eleve hátrányos, gettósodott körülmények között müködő oktatási-nevelési program nem vagy csak kis mértékben képes hozzáadni valamit az amúgy is alacsony kompetenciaszinttel rendelkező roma gyerekek tudásához.

\section{Tanulságok, összegzés}

A bemutatott népszámlálási, kutatási és OKM-adatok sok szempontból használhatók a roma tanulókkal kapcsolatos oktatási kérdések értelmezésére, az esetleges oktatáspolitikai beavatkozások megalapozására. Jelen tanulmány keretében csak néhány fontosnak gondolt adatsort mutattunk be azzal a céllal, hogy egy-két oktatáspolitikai beavatkozási lehetőségre rámutassunk. Ugyanakkor jeleztük azt is, hogy a roma népesség meghatározása önmagában is sok kérdést vet fel, hiszen a különféle - akár hivatalosnak is számító - összeírások, etnikai adatgyüjtések eltérő módszertanokat használhatnak.

A romának gondolt tanulók jelenléte önmagában nem kellene semmilyen nyelvietnikai kihívást jelentsen, hiszen az esetek zömében - a népszámlálási adatok tanúsága szerint - szintén magyar anyanyelvű népességről van szó. Az igazi kihívást a roma populáció társadalmi szerkezetben elfoglalt helye jelenti: mivel az alsóbb társadalmi rétegekbe, gyakran társadalmon kívüli élethelyzetekbe szorulva élnek, ez visszahat az iskolai eredményességükre. Soraikban így magasabb az iskolai lemorzsolódás, alacsonyabb iskolai végzettséghez és ezáltal gyengébb munkaerőpiaci pozíciókhoz jutnak. Mivel önmagát erősítő folyamatokról van szó, amelyet még tetéznek a társadalmi elöítéletek is, nehéz rendszerszintü beavatkozással érdemi változást elérni. A családi háttérbe „belenyúlni” csak a munkaerőpiaci státus változtatásával és talán a felnőttek folyamatos oktatásával, illetve kollégiumi elhelyezkedés biztosításával lehetséges. Az is megfontolandó, hogy ugyan jobbára magyar anyanyelvű népességről van szó, ám a családi háttér kontroll alatt tartása után is úgy tűnik, az iskolai romaarány és a szövegértés-kompetenciák között fennmarad egyfajta negatív kapcsolat: ez talán azt jelzi, hogy az alkalmazott pedagógiai módszerek nem minden esetben tudnak hatékonyak lenni, vélhetően nem megfelelőek az alsóbb társadalmi rétegekből származó és így eltérő habitussal, nyelvi kompetenciával rendelkező gyerekek számára. Az adatok szintjén az is látszik, hogy a roma tanulók mintegy ötöde részt vesz cigány nemzetiségi programban, ám e részvételnek nincs számottevő nyoma a mért kompetenciák szintjén.

Részben a népszámlálási adatok, ám az OKM-adatok is meggyőzően világítanak rá a térségi jellegzetességekre is. A roma tanulók oktatása sok szempontból kisebb falvakban (és kis iskolákban) zajló oktatási formát is jelent, amelynek előnyei és hátrányai egyaránt lehetnek. Külön kitértünk a szegregáció jelenségére is: a térségi, nem önkéntes szegregációról szintén kijelenthetjük, hogy nem a jelenség puszta léte a gond, hanem az, hogy az etnikai és szociális szegregáció összefügg az iskolai eredményességgel, hosszabb távon pedig egy társadalom versenyképességére is negatívan kihat. Kimutattuk, hogy a járások között különbséget tehetünk a szegregálódás jellege alapján, ami rávilágíthat arra

15 2018-ra vonatkozóan ld. 9. táblázat, 3. modell, 2017-es adatok szintjén a cigány nemzetiségi oktatásnak nincs szignifikáns hatása. 
is, hogy eltérő beavatkozások szükségesek a járások szintjén, azaz helyet kellene adni a lokális megoldásoknak is. Míg a gettósodott térségekben vélhetően visszafordíthatatlan folyamatok érvényesülnek, és ezért speciális megoldások szükségesek, addig a gettósodó térségek egy részében vagy a mérsékelten szegregáló járásokban még törekedni lehet valamilyen mértékủ integrációra vagy együttnevelésre, a gettósodás megakadályozására vagy fékezésére. Ehhez természetesen helyi akarat, az oktatási útvonalak térségi szintü tervezése és rendszerszintű támogatások is szükségesek lennének, ám a jelenlegi szabad iskolaválasztás gyakorlata és az egyházi intézmények állami támogatottsága e folyamatok ellenében hatnak. A vegyes etnikai arányú térségekben és településeken a szülők iskolaválasztását a romaarány, illetve a roma tanulókkal kapcsolatos vélt vagy valós sérelmek is befolyásolják, és úgy tűnik, a rendszer magára hagyta az iskolákat is és a szülőket is, akik értelemszerüen a mutatkozó lehetőségek alapján hoznak döntéseket vagy alakítják ki intézményi vagy egyéni stratégiáikat.

Természetesen tudatában vagyunk annak, hogy az elmúlt évtizedekben és jelenleg is többféle paradigmában értelmezve sokféle megoldás, javaslat, stratégia született a roma tanulók integrációja és/vagy felzárkózása/felzárkóztatása, a pedagógiai kultúra sokszínübbé tétele éljából. A szegregáció csökkentésének vagy felszámolásának deklarált célja nemcsak a nemzetközi, hanem a hazai, akár újabb keletủ stratégiai dokumentumokban is jelen van. ${ }^{16}$ Ráadásul a romákat nagy mértékben érintő társadalmi felzárkózás 2019 májusától a BM hatáskörébe került (amelynek adminisztratív vonatkozásain túlmenően szimbolikus vonatkozása is lehet), ugyanakkor több kormányzati és civil szervezeti egyeztető fórum is müködik. ${ }^{17}$ Mindezen erőfeszítések ellenére a szociális és etnikai alapú szegregálódás folyamatosnak tekinthető, az oktatási rendszer beazonosítható szegmensei olyan párhuzamos pályákra álltak, amelyek a társadalmi egyenlőtlenségek élesedéséhez és újratermelődéséhez, valamint a társadalmi szolidaritás csökkenéséhez vezetnek.

\section{Köszönetnyilvánítás}

A tanulmány az Iskola nem sziget NKFIH 120400 sz. projekt keretében készült.

\section{IRODALOM}

Bernát, A. (2018) A magyarországi romák társadalmi integrációja a 2010-es években. In: Kolosi T. \& Tóth I. Gy. (eds) Társadalmi riport 2018. Budapest, Tárki. pp. 144-165.

Brubaker, R. (2001) Csoportok nélküli etnicitás. Beszélö, Vol. 6. Nos 7-8. pp. 60-66.

16 A kormányzat ún. Antiszegregációs Kerekasztalt is müködtet, amellyel az „a szándéka hogy minden olyan szegregált iskolai működésmódot, ami akadályozza a hátrányos helyzetű gyerekek felzárkózását, ne csak szabályozással tiltsa, hanem hatékony intézkedéseket hozzon a spontán és szándékosan kierőltetett társadalmi különállás felszámolására”. Ld. Magyar Nemzeti Társadalmi Felzárkózási Stratégia. Tartósan rászorulók - szegény családban élő gyermekek - romák. (2011-2020). Frissített változat. EMMI Szociális Ügyekért és Társadalmi Felzárkóztatásért Felelős Államtitkárság. 122. Letöltve innen: http://romagov. hu/download/magyar-nemzeti-tarsadalmi-felzarkozasi-strategia-ii/

17 Társadalmi Felzárkózási és Cigányügyi Tárcaközi Bizottság, Roma Koordinációs Tanács, Nemzeti Stratégia Értékelő Bizottság, Roma Platform, Felzárkózást Segítő Gazdasági Fórum, Emberjogi Munkacsoport - Roma Tematikus Munkacsoport stb. 
ErCse K. (2018) Az állam által ösztönzött, egyházasszisztált szegregáció mechanizmusa. In: Fejes J. B. \& Szücs N. (eds) Én vétkem. Helyzetkép az oktatási szegregációról. Szeged, Motiváció Oktatási Egyesület. pp. 177-200.

Fejes J. B. \& Szứcs N. (2018, ed.): Én vétkem. Helyzetkép az oktatási szegregációról. Szeged, Motiváció Oktatási Egyesület.

Havas G. \& Liskó I. (2005) Szegregáció a roma tanulók általános iskolai oktatásában. Budapest, Felsőoktatási Kutatóintézet.

KapitáNy B. (2015) A magyarországi történelmi kisebbségi közösségek demográfiai viszonyai és perspektívái 1990-2011 között. Kisebbségkutatás, Vol. 24. No. 3. pp. 69-101.

Kertesi G. (2005) A társadalom peremén. Romák a munkaeröpiacon és az iskolában. Osiris, Budapest.

Lajtai M. (2020) Nemzetiségi viszonyok és a statisztikai adatgyűjtés Magyarországon. Statisztikai Szemle, No. 6. pp. 547-572. DOI: 10.20311/stat2020.6.hu0547

Magyar Nemzeti Társadalmi Felzárkózási Stratégia. Tartósan rászorulók - szegény családban élö gyermekek - romák (2011-2020). Frissített változat. EMMI Szociális Ügyekért és Társadalmi Felzárkóztatásért Felelős Államtitkárság. 122. http://romagov.hu/ download/magyar-nemzeti-tarsadalmi-felzarkozasi-strategia-ii/

Magyar Statisztikai Évkönyv 2019

Morauszki A. \& Papp Z. A. (2014) Nemzetiségi revival? Magyarország nemzetiségei a 2011. évi népszámlálás megváltozott módszertana tükrében. Kisebbségkutatás, Vol. 23. No. 3. pp. 73-98.

Orsós A. (2015): Cigány/roma nemzetiségi oktatás. Kutatási beszámoló. Pécs, Pécsi Tudományegyetem Bölcsészettudományi Kar Neveléstudományi Intézet Romológia és Nevelésszociológia Tanszék Wlislocki Henrik Szakkollégium.

PApp Z. A. (2011) A roma tanulók aránya Magyarországon és a tanulói teljesítmények az általános iskolai oktatásban. In: BÁrdi N. \& Tótr A. (eds) Asszimiláció, integráció, szegregáció. Párbuzamos értelmezések és modellek a kisebbségkutatásban. Budapest, MTA Kisebbségkutató Intézet, Argumentum. pp. 227-264.

Pénzes J., Tátrai P. \& PÁsztor I. (2018) A roma népesség területi megoszlásának változása Magyarországon az elmúlt évtizedekben. Területi Statisztika, Vol. 58. No. 1. pp. 3-26. DOI: 10.15196/TS580101

VARGA J. (2019, ed.) A közoktatás indikátorrendszere 2019. KRTK, KTI, Budapest. https://www.ksh.hu/sajtoszoba_kozlemenyek_tajekoztatok_2021_02_06 [Letöltve: 2021.09. 07.]

A cikk a Creative Commons Attribution 4.0 International License (https://creativecommons.org/licenses/ by/4.0/) feltételei szerint publikált Open Access közlemény, melynek szellemében a cikk bármilyen médiumban szabadon felhasználható, megosztható és újraközölhető, feltéve, hogy az eredeti szerző és a közlés helye, illetve a CC License linkje és az esetlegesen végrehajtott módosítások feltüntetésre kerülnek. (SID_1) 